\title{
sciendo
}

\section{RAPID DECREASING OF A SELECTED PLANT SPECIES DISTRIBUTION WITHIN RECENT DECADES AS AN ILLUSTRATION OF GRADUAL LOCAL EXTINCTION OF LOW-PRODUCTIVE WET MEADOW SPECIES IN CENTRAL EUROPE}

\author{
JAN OULEHLA ${ }^{* 1}$, MARTIN JIROUŠEK ${ }^{2,3}$, MILADA ŠŤASTNÁ ${ }^{1}$, \\ PETRA MARTÍNEZ BARROSO ${ }^{1}$
}

\author{
${ }^{1}$ Department of Applied and Landscape Ecology, Faculty of AgriSciences, Mendel \\ University, Zemédělská 1, 61300 Brno \\ ${ }^{2}$ Department of Plant Biology, Faculty of AgriSciences, Mendel University, Zemědělská 1, \\ 61300 Brno \\ ${ }^{3}$ Department of Botany and Zoology, Faculty of Science, Masaryk University, Kotlářská 2, \\ 61137 Brno \\ *Corresponding author's email: jan.oulehla@mendelu.cz
}

Received: $26^{\text {th }}$ January 2021, Accepted: $7^{\text {th }}$ April 2021

\begin{abstract}
This study provides an illustration of the contemporary extinction trend of a selected wet grassland species, Pedicularis sylvatica, within a region of the Bohemian-Moravian Highlands, Czech Republic. Historically, it was a relatively common species in the study region, but it has been severely reduced in recent decades due to the abandonment of the traditional management of the grasslands, or inappropriate management practices, including extensive drainage, fertilisation, and liming. Low precipitation in recent years, a depleted soil seed bank, inbreeding in small, isolated populations, the inability to germinate, and the emergence of seedlings can also play an important role. After personal resurvey, $P$. sylvatica was not confirmed on $28 \%$ of the localities where it was documented between two and 20 years ago. In a selected south-eastern subregion, only one of 19 localities persist nowadays. A steep decrease of local subpopulations of $P$. sylvatica points to the holistic problem of both the low-productive wet meadow species' extinctions and their habitat collapses in central Europe. Without proper protection and management, it is likely that low-productive wet meadows will continue to decline and, in the next few decades, only a fraction of today's already faint frequency will remain within a few higher-elevated subregions.
\end{abstract}

Keywords: biodiversity, plant extinction, degradation of wetlands, nature protection

\section{INTRODUCTION}

Low-productive wet meadows, including fen grasslands, are among the most endangered habitats in the Czech Republic (Chytrý et al., 2019) as well as many other European countries (Bragg \& Lindsay, 2003; van Diggelen et al., 2006; Lammers et al., 2015). The problem with fens and low-productive wet meadows is, on the one hand, the overall decrease in the number 
of localities or a reduction in the area of individual localities, but, on the other hand, the degradation of existing localities from the point of view of biodiversity (Soomers et al., 2013, Bergamini et al., 2009; Janssen et al., 2016; Chytrý et al., 2019). According to international IUCN criteria (Keith et al., 2013; Chytrý et al., 2019), both the area of the fens and their abiotic and biotic quality decreased in the Czech Republic by at least $80 \%$ over the last 50 years (Chytrý et al., 2019). The situation in other European countries differs, with worse situations in western and central Europe in contrast to northern and eastern Europe (Janssen et al., 2016). The most relevant threats to fen and wet meadow species have recently been connected to the abandonment of hay meadows, the lack of mowing, and subsequent changes due to natural succession (Chytrý et al., 2019). Modification of hydrographic functioning (extensive drainage in the past) and eutrophication (due to direct fertilisation or run-off water from neighbouring land) further accelerate these changes (Růžička, 1989; Grootjans et al., 2005; van Diggelen et al., 2005; Koch \& Jurasinski, 2014; Chytrý et al., 2019). The presence of plants of a lower height, including bryophytes, adapted to stressful wet and nutrient-poor conditions is threatened. Higher nutrient input and the absence of mowing or grazing support the expansion of common tall grasses and herbs with subsequent change into a habitat of low quality from the point of view of biodiversity.

A similar scenario with regards to habitats can also be observed for the individual plant species of low-productive wet meadows. Direct comparisons between historical and recent data concerning species' presence are mostly impossible due to lack of useful historical data. For such plant species, threat evaluation in the Red Lists had to be done based on an expert's estimations rather than on real data comparisons. This is exactly the case of Pedicularis sylvatica, which is evaluated to be a vulnerable species according to the last Red List of the Czech Republic, with an estimated loss of approximately 50-90\%, contrary to recent decades (category VU/C2t; Grulich, 2017).

Selecting a well-recognised threatened plant species in field (Pedicularis sylvatica), we aim to evaluate the real regional change in a number of localities over the last 20 years and changes in individual numbers in visited localities. We also aim to assess the specific causes of species' retreats with regards to human impact. In addition, the study provides an update of the species' occurrence, which will be useful for nature conservation authorities.

\section{MATERIALS AND METHODS}

\section{Study area}

The Bohemian-Moravian Highlands was selected as a study area due to the common occurrence of Pedicularis sylvatica in the past as well as the existence of a set of historical data necessary for direct comparisons, the latter at least for one subregion.

The study area is formed by hills and low mountains (approximately 500-837 m a.s.1.) and relatively densely settled lowlands in the central part of the Czech Republic. The crystalline bedrock dominates the study area of the Bohemian-Moravian Highlands (mostly gneiss, granite, and granodiorite), whereas alkaline types such as granodiorites or serpentinites are rare. Annual precipitation in this area is $673 \mathrm{~mm}$ according to the longterm average precipitation between 1981 and 2010. The average temperature according to the same range is $7.4^{\circ} \mathrm{C}$ (Tab. 1, Fig. 1).

The Bohemian-Moravian Highlands is considered one of the most important refuges of low-productive wet meadow species in the Czech Republic, not only with regards to vascular plants (Rybníček, 1966; Peterka et al., 2016; Roleček et al., 2020), but also bryophytes (Štechová et al., 2012; Hájek et al., 2015) and molluscs (Horsák et al., 2017). The highest concentration of low-productive wet meadows has most recently been in the central (Jihlava 

gradual local extinction of low-productive wet meadow species in central Europe

subregion), north-eastern (Žd'árské vrchy Hills, Žd’ár nad Sázavou subregion), and southwestern parts (Jindřichův Hradec subregion), whereas in other parts at lower altitudes they mostly disappear due to the abandonment of traditional land use, the intensification of agriculture, afforestation, and drainage, among other reasons (Růžička, 1987; Lysák, 2000; Oulehla et al., 2018; Oulehla \& Jiroušek, 2019).

Table 1 Characteristics of studied subregions.

Climatic data are measured data from stations of the Czech Hydrometeorological Institute (CHMI): subregion Velké Meziř́číi (Velké Meziřičí), subregion Žd’ár nad Sázavou (Vatín, Žd'ár nad Sázavou), subregion Pelhřimov (Nový Rychnov, Pelhřimov). The data are the average of values from 1981-2010. Altitude data are rounded averages taken according to the studied localities in the subregions.

\begin{tabular}{|l|r|r|r|}
\hline subregion & \multicolumn{1}{|l|}{ altitude } & \multicolumn{1}{l|}{ annual precipitation } & \multicolumn{2}{l|}{ average temperature } \\
\hline Velké Meziříi & 550 & 591.7 & 7.74 \\
\hline Žd'ár nad Sázavou & 650 & 695.6 & 6.95 \\
\hline Pelhřimov & 650 & 735.9 & 6.9 \\
\hline
\end{tabular}

Fig. 1 Average monthly precipitation for last three years, 2018, 2019, 2020, in comparison with the long-term average precipitation for the period of 1981-2010

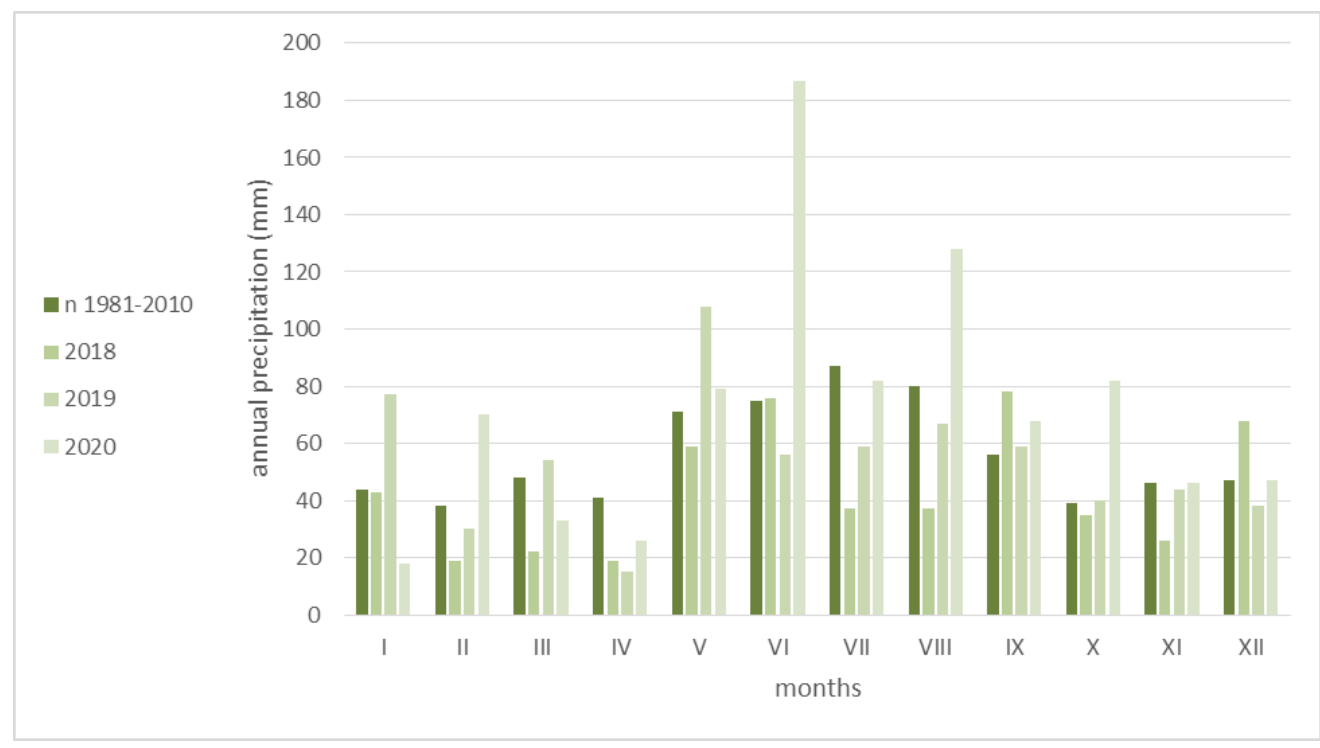

\section{Model plant species}

Pedicularis sylvatica is a semi-parasitic biennial herb germinating and reaching the juvenile rosette stage in the first year, and blooming and producing the seeds in the second year (Hrouda, 2000). It creates haustoria on the roots of higher plants, without specification of the host species (Gibson \& Watkinson, 1989). Both the monocotyledonous and dicotyledons, e.g. Avenella flexuosa, Carex nigra, C. pallescens, Danthonia decumbens, Nardus stricta, Polygala vulgaris, Succisa pratensis, and even other examples of P. sylvatica, were found as host plants (Ebermanová, 2015). P. sylvatica is characterized by a low competitive ability. Therefore, it prospers in the Czech Republic in nutrient-poor 
habitats like acidic moss-rich fens and peatland meadows (Caricion canescenti-nigrae) or Nardus grasslands (Violion caninae, Nardo strictae-Juncion squarrosi), where the competition for light is not too high (Gibson \& Watkinson, 1992; Chytrý, 2007; 2011). In addition, it also occurs in transitional mires (Sphagno-Caricion canescentis), managed wet Cirsium meadows (Calthion palustris) or heathlands (Genisto pilosae-Vaccinion; Sádlo et al., 2007; Chytrý, 2007, 2011). Occurrence in nutrient-poor habitats is typical for the whole group of semi-parasitic plants (Těšitel et al., 2015). In nutrient-rich habitats like wet meadows its occurrence depends on regular mowing or grazing. Clearing away the organic matter after mowing is necessary for removing nutrients from the locality. Preventing further direct fertilisation and the input of nutrients from the surrounding lands is important as well (Oulehla et al., 2018; Oulehla \& Jiroušek, 2019). The higher presence of individuals on pastures, meadows mowed with a heavy tractor, footpaths, or road margins demonstrates the importance of disturbed patches for the attachment of seedlings and the population development (Petrů \& Lepš, 2000). Pedicularis sylvatica is commonly found recently within a sub-atlantic temperate Europe (Kaplan, 2012), whereas the number of localities decreased significantly in central Europe (e.g., Sotek et al., 2016; Niklfeld and Schratt-Ehrendorfer, 1999; Grulich, 2017; Eliáš et al., 2016). Historical and recent findings within the Czech Republic can be traced in the PLADIAS database scattered in all of the upland and mountain regions or South Bohemian basins (Wild et al., 2019).

\section{Field botanical survey}

A detailed floristic survey was localised to three subregions of the Bohemian-Moravian Highlands: a north-western subregion (Pelhřimov), a north-eastern subregion (Žd'ár nad Sázavou) and a south-eastern subregion (Velké Meziříćí), each of them being the same area (four quadrants of the Central European grid system-CEBA) (Fig. 2).

Fig. 2: Localisation of the study area in the Czech Republic

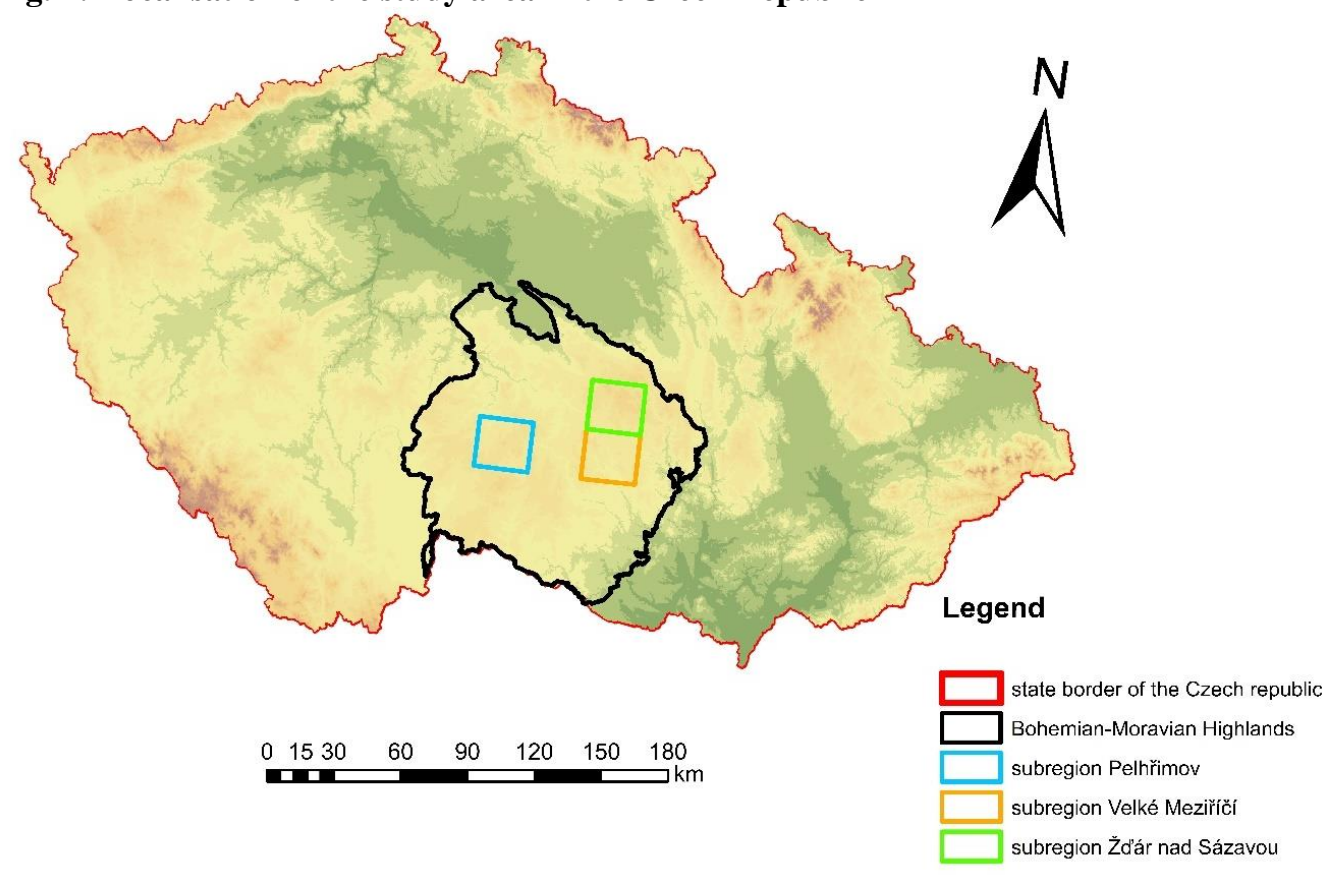


The boundaries of the subregion are identical to the Central European Basic Area (CEBA) grid system-Žd'ár nad Sázavou (quadrants 6461, 6462, 6361, and 6362), Velké Meziř́íćí (quadrants 6661, 6662, 6561, and 6562), and Pelhřimov (quadrants 6657, 6658, 6557, and 6558). During the vegetation season of 2020, monitoring of all localities with historical occurrence of Pedicularis sylvatica was carried out to update the occurrence of the species. The abundance was stated according to the presence of the species in the locality as individuals (one to ten individuals), dozens (11-100 individuals), hundreds (100-1000 individuals) or thousands (more than 1000 individuals). A total of 81 localities of historical occurrence were revised in the studied subregions. Information on local management and hydrological conditions was recorded directly in the field.

\section{Comparison with historical species distribution}

To illustrate the change in the species abundance, information about the previous occurrence was obtained from literature, floristic databases (Čech et al., 2017; Wild et al., 2019), floristic inventarisations of Nature Conservation Agency of the Czech Republic (AOPK С̆R, 2020), and personal communication. Only occurrences from recent decades (after 2000) were taken into account, with the exception of the south-eastern subregion of Velké Meziříćí, where more detailed information about historical occurrence exists. Then, a change in the species' retreat in Velké Meziř́ičí subregion could be visualised in the decades after 1990 (Lysák, 2000; Oulehla et al., 2018). In case that abundances were recorded in historical sources only as 'rare', 'scattered', or 'abundant', we assigned these to our grades (rare = individuals; scattered $=$ dozens; abundantly $=$ hundreds).

\section{Soil sampling and laboratory measurements}

To assess the possible impact of soil chemistry on the survival or decline of $P$. sylvatica populations in the region, soil samples were taken from 22 localities across the Bohemian-Moravian Highlands. The soil samples were distributed representatively for localities with numerous populations ( 8 samples) and weak populations ( 7 samples), as well as localities with only a historical occurrence (7 samples). Each of the soil samples consists of 30 individual subsamples taken from the locality by a needle probe. Individual soil subsamples were taken close to the plants of $P$. sylvatica, or they were taken based on the historical location of the populations in the case that the species occurrence was not confirmed. Samples were collected in PE bags and then deaerated and frozen. The collection of all samples was carried out within two days in late July. The ph $\left(\mathrm{H}_{2} \mathrm{O}\right), \mathrm{NO}_{3}, \mathrm{NH}_{4}, \mathrm{Ca}, \mathrm{P}$, $\mathrm{K}, \mathrm{Mg}$, $\mathrm{Na}$, and $\mathrm{Fe}$ were analysed in the accredited laboratory ENVIRO EKOANALYTIKA, s.r.o., Velké Meziříčí, Czech Republic. The Mehlich III method was used to determine macroelements. All measured macroelements are numbered as a $\mathrm{mg} / \mathrm{kg}$ of dry matter.

\section{Data processing and statistics}

To illustrate the differences in the distribution of the species in the three selected subregions of the Bohemian-Moravian Highlands, maps of the current occurrence of the species were created (Esri ArcGIS). A table with localities of the occurrence was created for the Velké Meziříčí subregion, where the size of the population is shown in the decades from 1990 onwards.

The soil samples were divided into three groups according to the size of the population (large population, small population (rare occurrence, individuals), or unconfirmed population where the species' extinction has a high probability). We tested for differences in 
the soil chemistry in the three population sizes using a Kruskal-Wallis test with the following non-parametric post-hoc comparisons (Statsoft, 2012).

\section{RESULTS}

\section{Occurrence of Pedicularis sylvatica}

81 localities with a reported occurrence of $P$. sylvatica after 2000 were revisited repeatedly in 2020. In total, the species was confirmed on 58 localities (72\%), whereas the study species was not confirmed on 23 localities ( $28 \%$ ) and it is considered extinct with high probability here. The distribution of large, small or not confirmed populations (probably extinct) was found with uneven distribution in the region of the Bohemian-Moravian Highlands. In the eastern part of the Pelhrimov subregion, a total of 23 localities of occurrence were revised (Fig. 3). There were five localities recorded with a population size of 1-10 individuals, 11 localities with a population size of 10-100 individuals, and a population of hundreds of individuals was found at three localities. The largest population in the entire study area was found in the Hajnice locality, numbering more than a thousand individuals. No occurrence was confirmed in three localities.

\section{Fig. 3: Current occurrence of Pedicularis sylvatica in the Pelhřimov subregion}

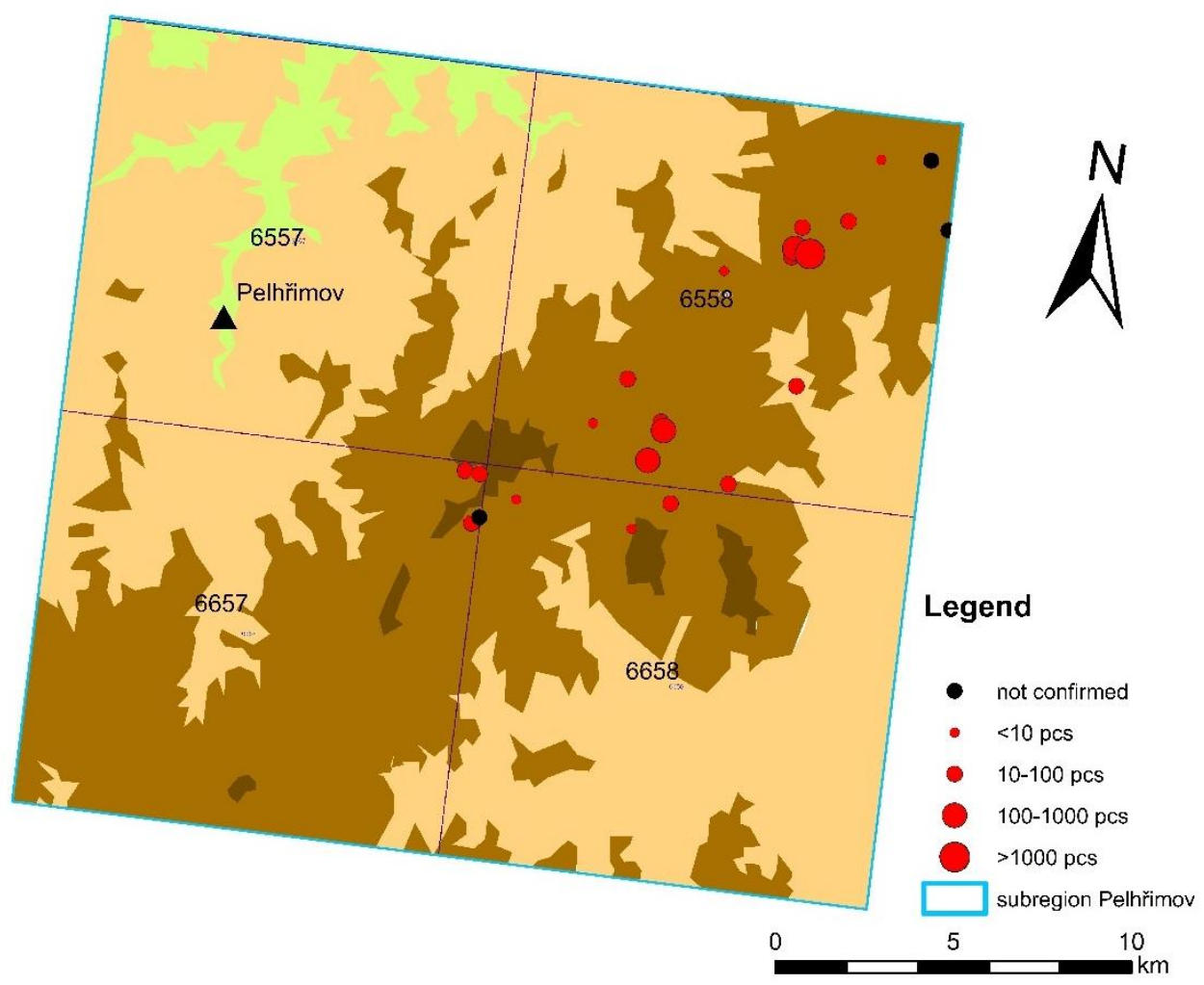

A total of 39 localities of the occurrence of Pedicularis sylvatica were revised in the Žd'ár nad Sázavou subregion (Fig. 3). There are many localities with smaller populations of 1-10 individuals (20 localities). Fifteen localities with populations of 10-100 individuals were 

gradual local extinction of low-productive wet meadow species in central Europe

recorded. Only two localities were recorded with populations larger than 100 individuals. No occurrence was confirmed in two localities. The largest populations are in the northern part, while in the southern part the populations are smaller and more scattered. A total of 19 localities were revised in the Velké Meziříćí subregion (Fig. 4). We recorded populations of 10-100 individuals in only one locality. This locality (Rendlíček pond, close to Březí nad Oslavou) is currently the southernmost locality in the eastern part of the Bohemian-Moravian Highlands. While the species occurred in a third of the localities five or even two years ago. Since 1990, the total number of localities in the subregion was reduced to $5 \%$ (Tab. 2).

Fig. 4: Current occurrence of Pedicularis sylvatica in the Žd’ár nad Sázavou and Velké Meziř́íći subregions

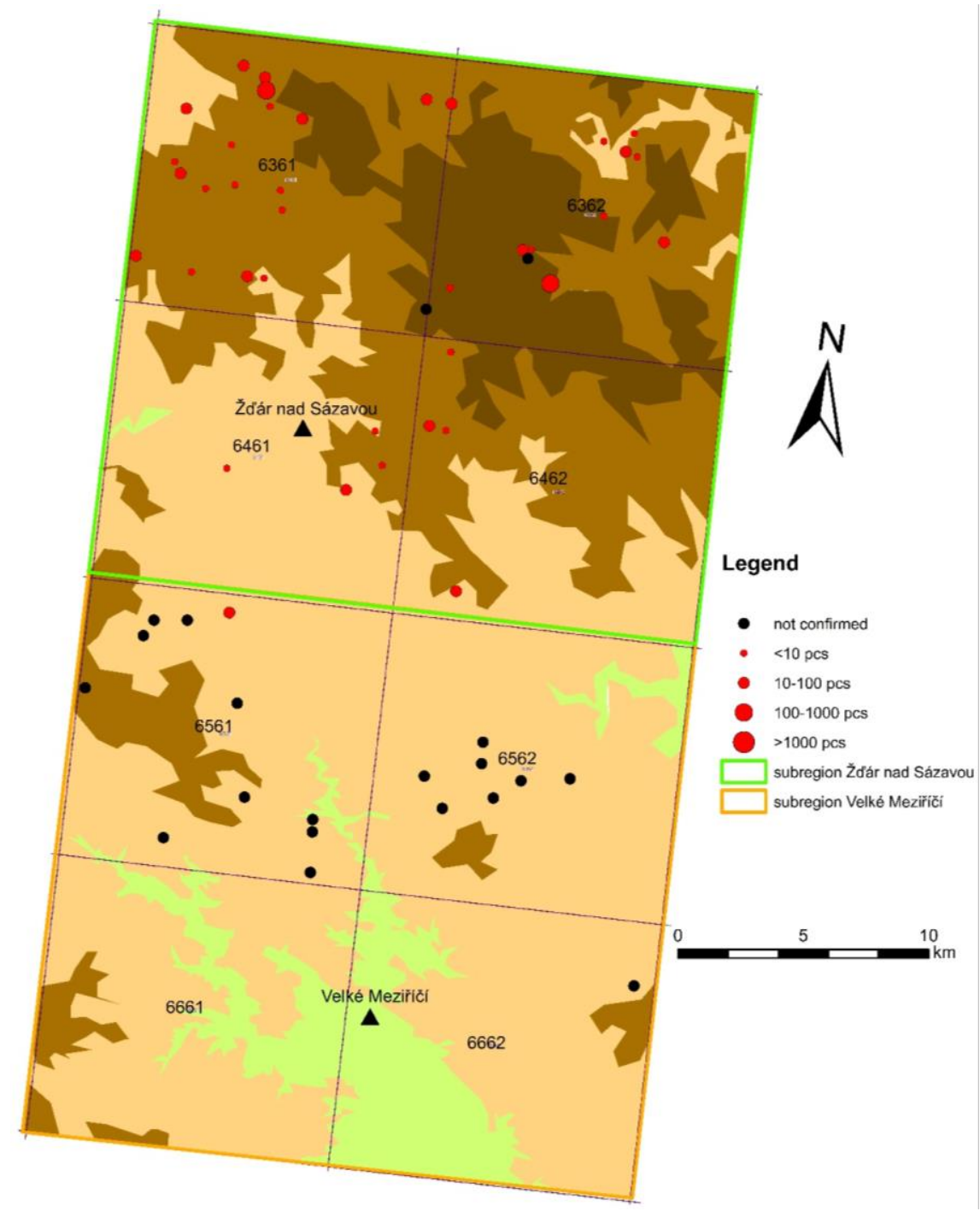


Table 2: Trend of extinction rate of Pedicularis sylvatica in the Velké Meziřričí subregion in the last three decades.

Direct interventions that caused the extinction of the species population are recorded: "P" plowing, "L" liming, "S" succession, "M" mulching, "F" afforestation

\begin{tabular}{|c|c|c|c|c|}
\hline \multirow[b]{2}{*}{ locality (coordinates WGS 84) } & \multicolumn{4}{|c|}{ population relative abundance } \\
\hline & $1990+$ & $2000+$ & $2010+$ & 2020 \\
\hline $\begin{array}{l}\text { Bobrůvecké studny } \\
\left(49^{\circ} 26^{\prime} 54.9^{\prime \prime} \mathrm{N}, 16^{\circ} 06^{\prime} 27.5^{\prime \prime} \mathrm{E}\right)\end{array}$ & $10-100 \mathrm{pcs}$ & $10-100 \mathrm{pcs}$ & not confirmed & not confirmed \\
\hline $\begin{array}{l}\text { Křest'anova louka } \\
\left(49^{\circ} 29^{\prime} 14.0^{\prime \prime} \mathrm{N}, 15^{\circ} 52^{\prime} 13.5^{\prime \prime} \mathrm{E}\right)\end{array}$ & $1-10 \mathrm{pcs}$ & $1-10 \mathrm{pcs}$ & not confirmed & not confirmed \\
\hline $\begin{array}{l}\text { Mrázkova louka } \\
\left(49^{\circ} 26^{\prime} 36.1^{\prime \prime} \mathrm{N}, 16^{\circ} 01^{\prime} 42.5^{\prime \prime} \mathrm{E}\right)\end{array}$ & $1-10 \mathrm{pcs}$ & not confirmed $(\mathrm{P})$ & not confirmed & not confirmed \\
\hline $\begin{array}{l}\text { Oudoly } \\
\left(49^{\circ} 22^{\prime} 38.3^{\prime \prime} \mathrm{N}, 16^{\circ} 09^{\prime} 19.8^{\prime \prime} \mathrm{E}\right)\end{array}$ & $10-100 \mathrm{pcs}$ & $1-10 \mathrm{pcs}$ & $1-10 \mathrm{pcs}$ & not confirmed \\
\hline $\begin{array}{l}\text { Pod Ochozem } \\
\left(49^{\circ} 24^{\prime} 15.3^{\prime \prime} \mathrm{N}, 15^{\circ} 58^{\prime} 16.6^{\prime \prime} \mathrm{E}\right)\end{array}$ & $\begin{array}{l}100-1000 \\
\text { pcs }\end{array}$ & $10-100 \mathrm{pcs}$ & $1-10 \mathrm{pcs}$ & not confirmed \\
\hline $\begin{array}{l}\text { Pod Spáleným rybníkem } \\
\left(49^{\circ} 29^{\prime} 21.1^{\prime \prime} \mathrm{N}, 15^{\circ} 53^{\prime} 15.6^{\prime \prime} \mathrm{E}\right)\end{array}$ & $10-100 \mathrm{pcs}$ & $1-10 \mathrm{pcs}$ & not confirmed & not confirmed \\
\hline $\begin{array}{l}\text { Pod Těšíkovým mlýnem } \\
\left(49^{\circ} 25^{\prime} 56.1^{\prime \prime} \text { N, } 16^{\circ} 02^{\prime} 20.4^{\prime \prime} \text { E) }\right.\end{array}$ & $1-10 \mathrm{pcs}$ & $1-10 \mathrm{pcs}$ & $1-10 \mathrm{pcs}$ & not confirmed \\
\hline $\begin{array}{l}\text { Sklenské studny } \\
\left(49^{\circ} 26^{\prime} 20.6^{\prime \prime} \mathrm{N}, 16^{\circ} 03^{\prime} 58.7^{\prime \prime} \mathrm{E}\right)\end{array}$ & $10-100 \mathrm{pcs}$ & $10-100 \mathrm{pcs}$ & $1-10 \mathrm{pcs}$ & not confirmed \\
\hline $\begin{array}{l}\text { U Čechova rybníka } \\
\left(49^{\circ} 26^{\prime} 44.7^{\prime \prime} \mathrm{N}, 16^{\circ} 04^{\prime} 50.8^{\prime \prime} \mathrm{E}\right)\end{array}$ & $10-100 \mathrm{pcs}$ & $10-100 \mathrm{pcs}$ & $1-10$ pcs (L) & not confirmed \\
\hline $\begin{array}{l}\text { U Chroustova } \\
\left(49^{\circ} 27^{\prime} 39.3^{\prime \prime} \mathrm{N}, 15^{\circ} 50^{\prime} 10.3^{\prime \prime} \mathrm{E}\right)\end{array}$ & $1-10 \mathrm{pcs}$ & $1-10$ pcs & not confirmed $(\mathrm{S})$ & not confirmed \\
\hline $\begin{array}{l}\text { U Kněžšského rybníka } \\
\left(49^{\circ} 25^{\prime} 24.0^{\prime \prime} \mathrm{N}, 15^{\circ} 58^{\prime} 08.8^{\prime \prime} \mathrm{E}\right)\end{array}$ & $10-100 \mathrm{pcs}$ & $10-100 \mathrm{pcs}$ & $\begin{array}{l}\text { not confirmed } \\
(\mathrm{M})\end{array}$ & not confirmed \\
\hline $\begin{array}{l}\text { U Kř̌iže } \\
\left(49^{\circ} 24^{\prime} 38.9^{\prime \prime} \mathrm{N}, 15^{\circ} 53^{\prime} 16.9^{\prime \prime} \mathrm{E}\right)\end{array}$ & $1-10 \mathrm{pcs}$ & not confirmed $(\mathrm{F})$ & not confirmed & not confirmed \\
\hline $\begin{array}{l}\text { U Nového rybníka } \\
\left(49^{\circ} 25^{\prime} 41.9^{\prime \prime} \mathrm{N}, 15^{\circ} 55^{\prime} 49.4^{\prime \prime} \mathrm{E}\right)\end{array}$ & $1-10 \mathrm{pcs}$ & $1-10 \mathrm{pcs}$ & $1-10 \mathrm{pcs}$ & not confirmed \\
\hline $\begin{array}{l}\text { U Rendlíčku } \\
\left(49^{\circ} 29^{\prime} 34.9^{\prime \prime} \mathrm{N}, 15^{\circ} 54^{\prime} 37.9^{\prime \prime} \mathrm{E}\right)\end{array}$ & $10-100 \mathrm{pcs}$ & $10-100 \mathrm{pcs}$ & $10-100 \mathrm{pcs}$ & $10-100 \mathrm{pcs}$ \\
\hline $\begin{array}{l}\text { U Sklenského rybníka } \\
\left(49^{\circ} 27^{\prime} 03.1^{\prime \prime} \mathrm{N}, 16^{\circ} 03^{\prime} 25.0^{\prime \prime} \mathrm{E}\right)\end{array}$ & $1-10 \mathrm{pcs}$ & $1-10 \mathrm{pcs}$ & not confirmed & not confirmed \\
\hline $\begin{array}{l}\text { U Voseckého rybníka } \\
\left(49^{\circ} 27^{\prime} 03.1^{\prime \prime} \mathrm{N}, 16^{\circ} 03^{\prime} 27.3^{\prime \prime} \mathrm{E}\right)\end{array}$ & $1-10 \mathrm{pcs}$ & $1-10 \mathrm{pcs}$ & not confirmed & not confirmed \\
\hline $\begin{array}{l}\text { U Záhumenního rybníka } \\
\left(49^{\circ} 28^{\prime} 45.9^{\prime \prime} \mathrm{N}, 15^{\circ} 51^{\prime} 58.6^{\prime \prime} \mathrm{E}\right)\end{array}$ & $1-10 \mathrm{pcs}$ & $1-10 \mathrm{pcs}$ & not confirmed $(\mathrm{F})$ & not confirmed \\
\hline $\begin{array}{l}\text { U Znětíneckého rybníka } \\
\left(49^{\circ} 27^{\prime} 38.5^{\prime \prime} \mathrm{N}, 15^{\circ} 55^{\prime} 15.1^{\prime \prime} \mathrm{E}\right)\end{array}$ & $10-100 \mathrm{pcs}$ & $10-100 \mathrm{pcs}$ & $1-10 \mathrm{pcs}$ & not confirmed \\
\hline $\begin{array}{l}\text { Zátoky } \\
\left(49^{\circ} 25^{\prime} 05.4^{\prime \prime} \mathrm{N}, 15^{\circ} 58^{\prime} 10.5^{\prime \prime} \mathrm{E}\right)\end{array}$ & $1-10 \mathrm{pcs}$ & $1-10 \mathrm{pcs}$ & not confirmed (S) & not confirmed \\
\hline
\end{tabular}



gradual local extinction of low-productive wet meadow species in central Europe

\section{Soil sample analysis}

Soil chemistry differed significantly among localities with different population sizes only in the case of a specific soil $\mathrm{pH}(\mathrm{p}=0.046)$ and follow-up tests demonstrated a significant difference in $\mathrm{pH}$ values only between localities with extinct and large populations (Fig. 5).

Fig. 5: Differences in soil chemistry among localities with extinct, small or large population of Pedicularis sylvatica are displayed (quartiles, medians, and marginal values of analysis).

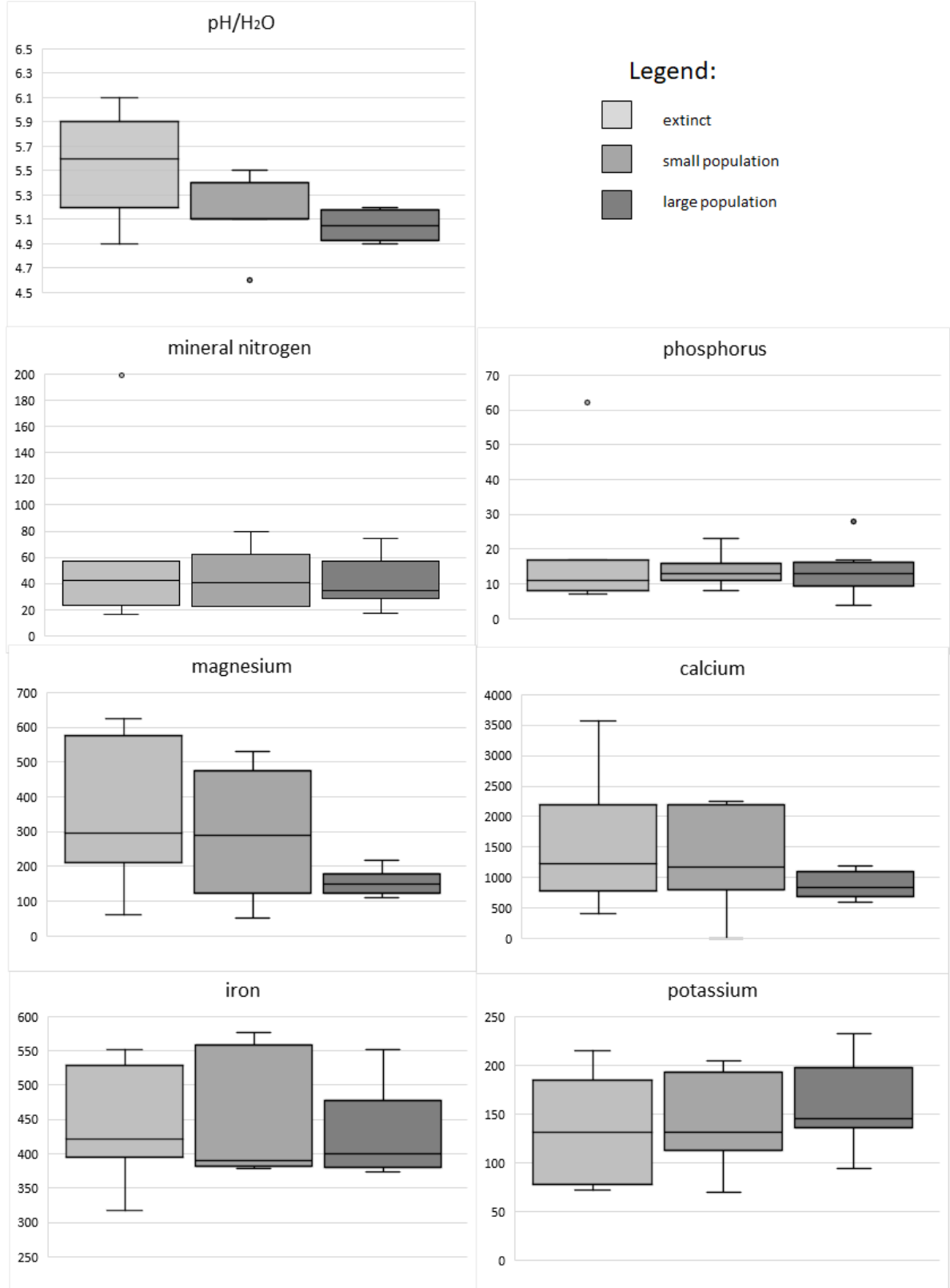


Magnesium and calcium concentrations were found to be relatively low in all localities with large populations, where they were more variable, also including relatively high $\mathrm{Mg}$ and Ca concentrations in the case of localities with small and extinct populations (this difference was not found as statistically significant at the level of significance where $p<0.05, p=0.103$ for $\mathrm{Mg}$, and $\mathrm{p}=0.206$ for $\mathrm{Ca}$ ). Mineral nitrogen (merged $\mathrm{N}-\mathrm{NH} 4$ and N-NO3), phosphorus, and potassium did not show any differences among tested groups of localities.

\section{DISCUSSION}

Compared to historical recordings, lower numbers of localities as well as lower numbers of individuals on localities were recorded in general during our survey. Our results point to the extinction of smaller populations in peripheral areas. Peripheral populations are more prone to extinction, compared to larger populations at the centre of the species range (Sotek et al., 2016; Lienert et al., 2002). On the other hand, the populations persist on localities of higher altitudes with more suitable climate. Moreover, thanks to well-care management it is possible to maintain populations in such localities. Approximately half of the localities is protected on a small scale and nature conservation management is implemented here. The other half is used for hay production in agriculture. Tractors with heavy mowing equipment is also possible to use if the site is large and not too waterlogged. For P. sylvatica it is possible to use different types of mowers including disc or bar mowers (Hejduk et al., 2017).

Due to higher temperatures in last years, lower stress caused by waterlogging, enables fast-growing vegetation competes so strongly with young seedlings that they do not have the chance to survive (Ebermanová, 2015). This applies to the dry springs that prevailed in April 2018, 2019, and 2020 (Fig. 1). The drought also has an indirect effect because, due to the decrease in humidity, nutrients are mineralised in fens, which causes their transformation into more-biomass-produced meadow types of vegetation (Chytrý, 2011). Such meadows have three times higher productivity than low-productive fen meadows or Nardus oligotrophic grasslands (Schelfhout, 2019).

The inconclusive differences in the analysis point to the fact that the change in the chemical parameters of the habitats is not crucial for current extinction trend in the region. With the exception of $\mathrm{pH}$ values and the associated liming, which does not benefit the strictly acidophilous species, its application is carried out in more intensively used agricultural areas. In wet meadows, degradation and reduction of the population of endangered species due to increased productivity of added nitrogen is known (Venterink et al., 2001). According to our analyses, the amount of nitrogen or phosphorus in all tested variants of localities is similar, without significant differences. The management practices related to the mowing and mown biomass removal probably suppress the direct importance of eutrophication.

As a frequent cause of the species' decline is often mentioned high height of the cut vegetation and insufficient turf disturbance (Čech et al., 2017). In our field surveys, the height was optimal in most localities and there were a lot of disturbances. A possible accompanying cause is the early term of mowing (at the beginning of May). During field surveys, direct damage of flowering individuals was also observed (Dudín-Zbilidy, Pod Ochozem, and Bobrůvecké studny localities). The flowering stems were cut off close to the ground, preventing the ripening. Spring dragging and the bowing of meadows can disrupt the turf, which can be considered similarly disturbing. Lysák (2000) points to several cases of species extinction after direct negative interventions connected to afforestation or ploughing.

Extinction of characteristic plant species substantially alters the character of the habitats and reduces their quality. The species Pedicularis sylvatica was selected as a model species to illustrate not only the change in the number of populations and changes in the sizes of 
populations, but overall quality decreasing of fen and wet meadow habitats in terms of biodiversity and ecological functioning. The extinction trend of fen and low-productive wet meadow species also applies to other co-occurring endangered plant species (Štípková \& Kindlmann, 2015; Lienert et al., 2002; Sotek et al., 2016), including bryophytes (Štechová et al., 2012). The most negatively affected populations in lower elevated subregions point to the extinction debt, i.e. extinction of species after a time lag between deterioration or destruction of habitats in the past and the subsequent disappearance of species in the future (Kuussaari et al., 2009). The only chance for the plant species of low productive fen and wet meadows to survive in the region of the Bohemian-Moravian Highlands is appropriate care in the best-preserved parts of higher altitudes, while the rest of the localities will probably disappear further in connection with the current climatic and socio-economic development. Our paper present rapid decreasing of population sizes of Pedicularis sylvatica as well as their overall lost in southeastern part of Bohemian-Moravian Highlands. However, the seeds may continue to be present in the soil and may re-regenerate if conditions and current management change.

\section{CONCLUSION}

Updated data about the occurrence of Pedicularis sylvatica in the Velké Meziříčí subregion showed how significantly and negatively the species range had changed. Out of the total number of 19 localities of occurrence, only one has been preserved. The causes of extinctions were partly documented (liming, unsuitable management practices), or they could be related to dry and warm climate (species extinction mainly in lower altitudes), and insufficient ability to reproduce and germinate seeds (low population size and lack of disturbances for seed germination). To maintain the occurrence of the species, it is necessary to eliminate negative direct interventions and continue good management, which will respect the mowing according to phenology of the species (late June). Outlook into the future is strongly dependent on climate change within next decades as well as activities of local farmers and nature protection authorities. In the current state of conditions, it is probable that the occurrence of Pedicularis sylvatica as well as other threatened species sharing the same localities will further decrease. Refugia then most likely remain only on higher altitudes of Žd'árské vrchy Hills and Jihlavské vrchy Hills in case the well set up management quality will be secured.

\section{ACKNOWLEDGEMENT}

The research was financially supported by the Mendel University internal grant agency of the Faculty of AgriSciences (MENDELU AF-IGA2020-IP014).

\section{CONFLICTS OF INTEREST}

The authors declare no conflict of interest. 


\section{REFERENCES}

AOPK ČR. (2020). Nature Conservancy Species Occurrence Finding Data Database [Online]. Retrieved June 5, 2020, from: http://portal.nature.cz.

Bergamini, A., Peintinger, M., Fakheran, S., Moradi, H., Schmid, B., Joshi, J. (2009). Loss of habitat specialists despite conservation management in fen remnants 1995-2006. Perspectives in Plant Ecology, Evolution and System 11, 65-79.

Bragg, O., Lindsay, R. (2003). Strategy and action plan for mire conservation in Central Europe. Wetlands International Publication 18. Wetlands International, Wageningen, NL.

Čech, L., Ekrt, L., Ekrtová, E., Jelínková, J., Juřička, J. (2017). Pedicularis sylvatica L. všivec lesní v Kraji Vysočina [Pedicularis sylvatica in the Vysočina Region]. [Online]. Retrieved June 2, 2020, from: http://prirodavysociny.cz/cs/druhy/911/vsivec-lesni [2-6-2020].

Chytrý, M. (2007). Vegetation of the Czech Republic. Volume 1. Grassland and Heathland Vegetation. Academia, Praha.

Chytrý, M. (2011). Vegetation of the Czech Republic. Volume 3. Aquatic and wetland vegetation. Academia, Praha.

Chytrý, M., Hájek, M., Kočí, M., Pešout, P., Roleček, J., Sádlo, J., Šumberová, K.,Sychra, J., Boublík, K., Douda, J., Grulich, V., Härtel, H., Hédl, R., Lustyk, P.,Navrátilová, J., Novák, P., Peterka, T., Vydrová, A., Chobot, K., (2019). Red list of habitats of the Czech Republic. Ecological Indicators 106, 105446.

van Diggelen, R., Middleton, B., Bakker, J., Grootjans, A., Wassen, M. (2009). Fens and floodplains of the temperature zone: Present status, threats, conservation and restoration. Applied Vegetation Science 9(2), 157-162.

van Diggelen, R., Sijtsma, J. F., Strijker, D., van den Burg, J. (2005). Relating land-use intensity and biodiversity at the regional scale. Basic and Applied Ecology 6, 145-159.

Ebermannová, P. (2015). Vybrané aspekty ekologie Pedicularis sylvatica [Selected aspects of the ecology of Pedicularis sylvatica]. Diploma thesis (in Czech), University of South Bohemia in České Budějovice

Eliáš, P., Dítě, D., Kliment, J., Hrivnák, R., Feráková, V. (2015). Red List of Ferns and Flowering Plants of Slovakia. Biologia 70(2): 218-228.

Gibson, C.C., Watkinson, A.R. (1989). The host range and selectivity of a parasitic plant: Rhinanthus minor L. Oecologia 78, 401-406.

Gibson, C.C., Watkinson, A.R. (1992). The role of the hemiparasitic annual Rhinanthus minor in determining grassland community structure. Oecologia 89, 62-68.

Grootjans, A. P., Hunneman, H., Verkiel, H., van Andel, J. (2005). Long-term effects of drainage on species richness of a fen meadow at different spatial scales. Basic and Applied Ecology 6(2), 185-193.

Grulich, V. (2017). Red List of vascular plants of the Czech Republic. In Grulich, V., Chobot, K. Red List of threatened species of the Czech Republic, vascular plants (pp. 75 132). Př́roda 35.

Hejduk, S., Svobodová, A., Krahulec, F. (2017). Mowing of grasslands. Standards of care for nature and landscape. Care of selected terrestrial habitats. Series D. SPPK D02 004: 2017. [Online]. Retrieved Marc 12, 2020, from: https://standardy.nature.cz/res/archive/ 414/068346.pdf?seek=1552472871. [12-03-2021].

Horsák, M., Hájek, M., Horsáková, V., Hlaváč, J., Hájková, P., Dítě, D., Peterka, T., Divíšek, 
Oulehla J. et. al.: Rapid decreasing of a selected plant species distribution within recent decades as an illustration of gradual local extinction of low-productive wet meadow species in central Europe

J., Potúčková, A., Preece, R.C. (2017). Refugial occurrence and ecology of the land snail Vertigo lilljeborgi in fen habitats in temperate mainland Europe. Journal of Molluscan Studies 83, 451-460.

Hrouda, L. (2000). Pedicularis L. - všivec. In Slavík, B. Květena České republiky 6 (pp. 455 - 461). Academia, Praha.

Kaplan, K. (2012). Flora and phytogeography of the Czech Republic. Preslia 84: 505-573.

Keith, D.A., Rodríguez, J.P., Rodríguez-Clark, K.M., Nicholson, E., Aapala, K., Alonso, A., Asmussen, M., Bachman, S., Basset, A., Barrow, E.G., Benson, J.S., Bishop, M.J., Bonifacio, R., Brooks, T.M., Burgman, M.A., Comer, P., Comín, F.A., Essl, F., Faber-Langendoen, D., Fairweather, P.G., Holdaway, R.J., Jennings, M., Kingsford, R.T., Lester, R.E., Nally, R.M., McCarthy, M.A., Moat, J., Oliveira-Miranda, M.A., Pisanu, P., Poulin, B., Regan, T.J., Riecken, U., Spalding, M.D., Zambrano-Martínez, S. (2013). Scientific Foundations for an IUCN Red List of Ecosystems. PLOS ONE 8(5), e62111.

Koch, M., Jurasinski, G. (2014). Four decades of vegetation development in a percolation mire complex following intensive drainage and abandonment. Plant Ecology and Diversity $8,49-60$.

Kuussaari, M., Bommarco, R., Heikkinen, R.K., Helm, A., Krauss, J., Lindborg, R., Öckinger, E., Pärtel, “ M., Pino, J., Rodà, F., Stefanescu, C., Teder, T., Zobel, M., Steffan-Dewenter, I. (2009). Extinction debt: a challenge for biodiversity conservation. Trends in Ecology \& Evolution 24(10), 564-71.

Lamers, L.P.M., Vile, M.A., Grootjans, A.P., Acreman, M.C., van Diggelen, R., Evans, M.G., Richardson, C.J., Rochefort, L., Kooijman, A.M., Roelofs, J.G.M., Smolders, A.J.P. (2015). Ecological restoration of rich fens in Europe and North America: from trial and error to an evidence-based approach. Biological reviews 90, 182-203.

Lienert J., Fischer, M., Diemer, M. (2002). Local extinctions of the wetland specialist Swertia perennis L. (Gentianaceae) in Switzerland: a revisitation study based on herbarium records. Biological conservations 103 (1), 65-76.

Lysák, F. (2000). Ohrožená mokřadní květena Velkomeziřičska a jeji ochrana [Endangered wetland flora of the Velkomeziríčsko region and its protection]. Diploma thesis (in Czech), Palacký Univerzity Olomouc.

Niklfeld, H., Schratt-Ehrendorfer, L. (1999). Rote Liste gefährdeter Farn- und Blütenpflanzen (Pteridophyta und Spermatophyta) Österreichs. 2. Fassung. In: Niklfeld, H. Rote Listen gefährdeter Pflanzen Österreichs. (pp. 33 - 152), 2. Auflage. Grüne Reihe des Bundesministeriums für Umwelt, Jugend und Familie, Band 10. Austria medien service, Graz.

Oulehla, J., Lysák, F., Jiroušek, M. (2018). Local extinctions of threatened species of Pedicularis L. in agriculture landscape of southeastern Bohemian-Moravian Highlands. In Proceedings of International PhD Students Conference MendelNet 2018 (pp. 205 - 210), Mendel University in Brno.

Oulehla, J., Jiroušek, M. (2019). Degradation of fens and wet meadows of southeastern Bohemian-Moravian Highlands after 20 years. In Proceedings of International PhD Students Conference MendelNet 2019 (pp. 315 - 320). Mendel University in Brno.

Peterka, T., Dítě, D., Hájková, P., Hájek, M. (2016). Ověření výskytu suchopýru štíhlého (Eriophorum gracile) ve Žd'árských vrších [Verification of the occurrence of Eriophorum gracile in Žd'árské vrchy Hills]. Východočeský sborník př́rodovědný. Práce a studie 23, 47- 


\section{6.}

Petrů, M., Lepš, J. (2000). Regeneration dynamics in populations of two hemiparasitic species in wet grasslands. In Proceedings IAVS Symposium (pp. 329 - 333). Uppsala, January 1999. Opulus Press Uppsala, Uppsala.

PLADIAS. (2018). Database of the Czech flora and vegetation. [Online]. Retrieved December 8, 2020, from: http://www.pladias.cz/.

Roleček, J., Svitavská Svobodová, H., Jamrichová, E., Dudová, L., Hájková, P., Kletetschka, G., Kuneš, P., Abraham, V. (2020). Conservation targets from the perspective of a palaeoecological reconstruction: the case study of Dárko peat bog in the Czech Republic. Preslia 92, 87-114.

Růžička, I. (1989). Výsledky záchranného výzkumu ohrožené květeny mizejících rašeliništ’ a rašelinných luk na Jihlavsku [The results of rescue research of endangered flora of disappearing mires and miremeadows in the Jihlavsko region]. Vlastivédný Sborník Vysočiny 9, 135-176.

Růžička, I. (1987). Výsledky záchranného výzkumu ohrožené květeny mizejících rašelinišst’a rašelinných luk v okolí Telče na Českomoravské vrchovině. [The results of rescue research of endangered flora of disappearing mires and miremeadows in the Telč region]. Vlastivědný Sborník Vysočiny 8, 153-192.

Rybníček, K. (1966). Glacial relicts in the bryoflora of the highlands Českomoravská vrchovina (Bohemian-Moravian Highlands); their habitat and cenotaxonomic value. Folia Geobotanica et Phytotaxonomica 1, 101-119.

Sádlo J., Chytrý M., Pyšek P. (2007). Regional species pools of vascular plants in habitats of the Czech Republic. Preslia 79: 303-321.

Schelfhout, S. (2019). Restoration of species-rich Nardus grasslands via phosphorus-mining. Doctor $(\mathrm{PhD})$ thesis. Ghent University.

Sommers, H., Karssenberg, D., Verhoeven, J.T.A., Verweij, P.A., Wassenm M.J. (2013). The effect of habitat fragmentation and abiotic factors on fen plant occurrence. Biodiversity and Conservation 22(2), 405-424.

Sotek Z, Stasińska M, Malinowski R, Meller E, Grzejszczak G, Kurnicki B. (2016). Distribution and habitat properties of Carex pulicaris and Pedicularis sylvatica at their range margin in NW Poland. Acta Societatis Botanicorum Poloniae 85(3),3507.

Štechová, T., Štech, M., Kučera, J. (2012). The distribution of Hamatocaulis vernicosus (Mitt.) Hedenas (Calliergonaceae) in the Czech Republic. Bryonora 49, 5.

Štípková Z., Kindlmann, P. (2015). Extent and reasons for meadows in south bohemia becoming unsuitable for orchids. European Journal of Environmental Sciences 5(2), 142 147.

Těšitel, J., Fibich, P., de Bello, F., Chytrý, M., Lepš, J. (2015). Habitats and ecological niches of root-hemiparasitic plants: an assessment based on a large database of vegetation plots. Preslia 87, 87-108.

Venterink, H.O., van der Vliet, R.E., Wassen, M.J. (2001). Nutrient limitation along a productivity gradient in wet meadows. Plant and Soil 234, 171-179.

Wild, J., Kaplan, Z., Danihelka, J., Petřík, P., Chytrý, M., Novotný, P., Rohn, M., Šulc, V., Brůna, J., Chobot, K., Ekrt, L., Holubová, D., Knollová, I., Kocán, P., Štech, M., Štěpánek, J., Zouhar, V. (2019). Plant distribution data for the Czech Republic integrated in the Pladias database. Preslia 91, 1-24. 